\title{
Intellectuals and Fascism in Interwar Romania: The Criterion Association (2019)
}

Cristina A. Bejan.

Cham: Palgrave Macmillan

Language: English

This volume introduces foreign readers to interwar Romania, an epoch characterized by rich paradoxes, when several young and brilliant intellectuals established the Criterion Association in 1932 Bucharest, 'deliberately structured to be a home for dynamic democratic timely debate' and a platform for conferences, symposia, artistic events and exhibitions, the association intended to present and critically analyze 'an array of new ideas in politics, economics, music, art, culture, philosophy, architecture, literature and more, from within and outside Romania.'

Cristina A. Bejan explores how the Criterion Association supported the infamous fascist Iron Guard, founded and led by Corneliu Zelea Codreanu. The rationale of the book is to show how important admitting the past is for a nation in order to rebuild itself. Even though Romania's intellectual cultural elite did not participate in Codreanu's ritual murders, they were still his ardent admirers, a fact that is often ignored nowadays.

The monograph contains a presentation of the spiritual leader of the Young Generation, Nae Ionescu: preacher of extreme right politics, professor of philosophy at University of Bucharest and editor of the fascist newspaper Cuvântul; then details the association's activities from its birth to its demise a few years later, when political allegiances led to irreconcilable positions of its members. The book also provides an excellent engagement with 'Rhinocerization,' the term coined by Ionesco in Les Rhinocéros, synonymous with Mircea Eliade's 'hooliganism': the attitude of revolt among university graduates who became extremists in a convulsive atmosphere that increased the Iron Guard's popularity. Apart from 
Jeni Acterian, Ionesco and the Jewish democrat, novelist and playwright Mihail Sebastian were the only Criterionists who regarded fascism 'as a stampede of wild animals and a terrifying loss of humanity.'

Whilst Ionesco, Emil Cioran, and Eliade made their names while in exile as one of the best creators of what Martin Esslin termed 'the theatre of the absurd' (Ionesco), a lionized French philosopher (Cioran), and a highly influential historian of religions (Eliade), other figures like Sebastian and the philosopher Constantin Noica are also fairly known outside Romania. However, there are Criterionists with whom only Romanian-speaking readers are familiar, and the main merit of the book is to make their profile known.

As Vladimir Tismăneanu rightly points out in the foreword, Bejan's documentation of the crucial role played by art historian and philosopher Petru Comarnescu in the Criterionist activities is impressive. Bejan brings evidence from Romania's National Council for the Study of the Securitate, the U.S. Holocaust Museum archives and Comarnescu's personal Archive.

Other Criterionists whose contributions Bejan engages with include actress and theater director Marietta Sadova, 'a convinced and active Legionnaire'; the Acterian siblings; philosopher Mircea Vulcănescu; political activist Mihail Polihroniade; lawyer and writer Alexandru Christian Tell; ballet dancers Floria Capsali and Gabriel Negry; leftist writer Zaharia Stancu; Ion I. Cantacuzino; Sandu Tudor, theologian, director of the slanderous traditional orthodox Credinţa that aligned with the Third Reich's politics of 'extreme antihomosexual repression,' publishing libels against four Criterionists referred to as 'inverts,' the 'mafia of the homosexuals,' 'parasites' and 'gypsies.' Bejan minutely details the Criterionists' envies, jealousies, truculence, animosities, their impatience to cleanse what they regarded as mediocrity, corruption and or deviancy. 
Perhaps the best characterization of Bejan's position in her insightful analysis would be fairness and a highly ethical commitment. She distances herself from Marta Petreu's claim that Cioran's texts contained nothing 'outrageous about anti-Semitism' and the late Ilinca Zarifopol-Johnston who saw in Romania's Transfiguration mainly a 'cry of despair and wounded pride,' concluding that many of Cioran's statements omitted in Petreu's book 'seem quite anti-Semitic.' However, Bejan doesn't give credit to the reckless allegations against Cioran for his controversial early work, mentioning his apologies and the excision of controversial fragments from its subsequent edition. At the same time, she exposes Eliade for never admitting his youthful mistakes.

Bejan's book proves to be an excellent guide to scholars studying Romania's agonizing years of gloom and doom and is a great research tool for future comparisons with other Eastern European countries where fascism grew to hyperbolic proportions. It may be also useful to those with an interest in investigating how former ideologies are sometimes partially re-staged through ongoing initiatives in Romanian realpolitik nowadays.

\section{ARLEEN IONESCU}

Shanghai Jiao Tong University 